\title{
Effect of Preheat on Tensile and Corrosion Properties of Steel Welded Joints
}

\author{
M. A. BAYOUMI* \& M.T.ELMESTEKAWI**
}

* Dept .of Mechanical Engineering, Al-Azhar University, Cairo, Egypt. ** Dept. of Mechanical Eng. Higher Technological Institute, $10^{\text {th }}$. of Ramadan City, Egypt .

\begin{abstract}
Steels of high carbon content, in general, have high strength, that makes them needed in many enginecring applications. However, the repair of components made of such steels through maintenance by welding presents a major problem. Therefore, in the present investigation a trial is made to find out a way to facilitate the welding of such high carbon, high strength steel with the objective to improve its mechanical properties. Preheating to different temperatures was carried out on different carbon content steels before butt weld joints were made. The joints were subjected to tension and corrosion tests. The results showed that there is a relation between the preheating temperature and the carbon content of the steel of interest. They showed that preheating in the range of $100-150^{\circ} \mathrm{C}$ improved the tensile strength of the tested steel of carbon content of $0.6,0.9$ and $1.55 \mathrm{wt} . \%$. Little improvement of ductility has been noted. Also, the results showed that, little effect for preheat on the corrosion resistance.
\end{abstract}

Manuscript received from Dr.W.T. ELMESTEKAWI on : 12/2/2000

Accepted on : 18/4/2000

Engineering Research Bulletin, Vol 23, No 3, 2000 .Minufiya University, Faculty of Engineering, Shebien El-Kom, Egypt, ISSN 1110-1180 


\section{INTRODUCTION}

In arc welding, the cooling rate has a pronounced effect on the final properties of the weld joint. Residual stresses of thermal nature are considered as a failure source in some applications, therefore some work has been done to avoid the presence of such stresses [1-2]. The main idea is to adjust the cooling rate in such a way to reduce or eliminate these stresses.

The weldablity of steels is usually expressed in terms of a carbon equivalent limit or a maximum value, as a general rule, a steel is considered weldable if its carbon equivalent is less than $0.4 \%$ [3]. This value is considered the upper limit of good weldablity without preheat. However, steels of high carbon content in many applications are needed to be weld either for construction purposes or for repair maintenance. In such situations a special care should be considered to obtain. reliable joints. One of the basic ideas is to adjust the cooling rate in such a way to control the solidification process and consequently the solidified phases and the residual stresses that may exist.

In order to cortrol the cooling rate, a preheating treatment is suggested in the present work, for steels of relative high carbon content and alloying elements, with the objective to find a correlation between the preheating conditions and the alloy composition to get the optimum mechanical performance.

For comparison, samples of each alloy were welded without preheating, that is, at room temperature (RT).

\section{EXPERIMENTAL PROCEDURES}

\subsection{Raw Materials}

Steel alloys of $0.6,0.9$ and $: .55$ wt.\% carbon content were used, their chemical composition is listed in table( $i$ ). The samples were received in the form of annealed $5 \mathrm{~mm}$ thick sheets.

Table (1): Chemical Composition, (wt.\% ), of the Tested Alloys

\begin{tabular}{|c|c|c|c|c|c|c|c|}
\hline $\mathrm{Sp} . \#$ & $\mathrm{C}$ & $\mathrm{Si}$ & $\mathrm{Mn}$ & $\mathrm{Cr}$ & $\mathrm{Mo}$ & $\mathrm{V}$ & $\mathrm{W}$ \\
\hline 1 & 0.6 & 0.35 & 0.8 & 4.5 & 0.5 & 0.2 & - \\
\hline 2 & 0.9 & - & 1.2 & 0.5 & - & - & 0.5 \\
\hline 3 & 1.55 & 0.3 & 0.3 & 1.2 & 0.8 & 0.8 & - \\
\hline
\end{tabular}

\subsection{Welding Procedures}

Welding is performed using electrodes of type Xuper 680S that are suitable for medium and high carbon steels. The chemical composition of the electrode is given in the following table. 
Table (2): Chemical Composition, (wt.\% ), of the Weld Electrode

\begin{tabular}{|c|c|c|c|c|c|}
\hline $\mathrm{C}$ & $\mathrm{Mn}$ & $\mathrm{Cr}$ & $\mathrm{Ni}$ & $\mathrm{Si}$ & $\mathrm{S}$ \\
\hline 0.12 & 2.68 & 14.65 & 0.95 & 0.35 & 0.022 \\
\hline
\end{tabular}

The actual welding parameters are listed in table (3). The samples are subjected to different prcheating temperatures namely: 100,150 , and $200{ }^{\circ} \mathrm{C}$, which werc mcasurcd by a thermocouple located near the prepared edges of each sample before welding inside the oven. The test was repeated three times for each preheating temperature.

Table (3): Welding Conditions

\begin{tabular}{|c|c|c|c|c|}
\hline $\begin{array}{c}\text { Electrode } \\
\text { Diameter } \\
(\mathrm{mm})\end{array}$ & \multicolumn{3}{|c|}{ Welding variables } & $\begin{array}{c}\text { Heat input } \\
(\mathrm{kJ} / \mathrm{mm})\end{array}$ \\
\hline \cline { 2 - 5 } & Current (A) & Arc voltage $(\mathrm{V})$ & $\begin{array}{c}\text { Welding speed } \\
(\mathrm{mm} / \mathrm{min})\end{array}$ & 1.15 \\
\hline 3.2 & 90 & 25 & 130 & 1.15 \\
\hline
\end{tabular}

\subsection{Geometry of Welding Samples}

The samples in the form of flat sheet of $5 \mathrm{~mm}$ thickness with a single Vee edge preparation, are butt welded in a single weld run. Figure (1.a) illustrates the sample geometry

\subsection{Tensile Properties}

All welded samples are tested in static tension test in order to evaluate the preheat effect on their mechanical properties. A comparison is carried out with samples welded without preheating, that is, at room temperature (RT). The samples are tested using an Instron machine, the machine cross head speed was $2.54 \mathrm{~mm} / \mathrm{min}$ that gives an initial strain rate of $8.4 \times 10^{-4} \mathrm{~s}^{-1}$ The samples dimensions and geometry are given in figure(1.b). The tensile properties namely the ultimate tensile strength and the ductility are measured.

s.

\subsection{Corrosion}

A laboratory potentionstat model bank LB -81 was used for measuring the corrosion rate for the welded specimen as well as the unwelded materials (blank alloys). The samples were wired to act as the working electrode, in an electric cell, composed of platinum electrode dipped in a tap water and connected through a salt bridge with a standard calomel reference electrode dipped in a $0.1 \mathrm{M} \mathrm{KCl}$ solution.

"The potential difference between the standard calomel electrode and that of the working electrode was varied with a constant rate of $20 \mathrm{mV} / \mathrm{min}$ and the corresponding current was recorded. A plot between the current $(\mathrm{mA})$ and the potential ( $\mathrm{mV}$ ) was constructed for each specimen. 


\subsection{Metallographic Examination}

The specimens that welded under different preheat conditions were prepared for microstructure observation, following the standard procedures. All the specimens were examined using an optical microscope.

\section{RESULTS AND DISCUSSIONS}

\subsection{Microstructure Observation}

The microstructure of $\mathrm{HAZ}$ is considered as controlling factor in the production of satisfactory weldments. The most important factor affecting $\mathrm{HAZ}$ microstructure is the cooling rate which is mainly influenced by preheating temperature. Macroscopic examinations of cross sections taken from welded joints with preheats of R.T., 100, 150 , and $200{ }^{\circ} \mathrm{C}$ disclosed that no visual welding defects were seen. However, it is found that the width of $\mathrm{HAZ}$ increases with the increase in preheating temperature.

For high carbon steel (1.55), a preheat temperature of $150^{\circ} \mathrm{C}$ is recommended, since preheating improves both the tensile strength and ductility (Figs:6, 7). Generally, the effects of the preheat is to minimize the possibility of cold cracking in the HAZ. Preheating reduces the cooling rate during and after austenite transformation, therefore, reducing martensite formation to a minimum. However, higher preheat temperature $\left(200{ }^{\circ} \mathrm{C}\right)$, are undesirable because the time at high temperature is increased, which enables the HAZ austenite to take more carbon into solution resulting in a matrix with high carbon which increases hardness and brittleness.

The polished and etched surfaces of the alloys of different carbon content that subjected to different preheat regimes, were examined using an optical microscope. The results are shown in figures 2-5. As it is expected preheat reduces the cooling rate resulting in the presence of different phases depending on the chemical composition of the alloy of concern. Figures 2 -a\&b, show the microstructure of the alloys of carbon content of about $0.6 \mathrm{C} \mathrm{wt. \%}$, that are welded without preheat and that subjected to $100{ }^{\circ} \mathrm{C}$ preheat respectively. It can be seen from these figures that preheat has a pronounced effect on the fusion between the weld metal (light area) and the base metal (dark area). This consequently has a significant effect on the mechanical strength of the welded alloys as it is shown in Figures 6 and 7. The strength is increased by about $60 \%$ due to preheat to $100{ }^{\circ} \mathrm{C}$ for this alloy.

Similar results were obtained for the other alloys, for example, for alloy of $0.9 \mathrm{C}$ wt. $\%$, as it shown in figure 3. Preheating to $100^{\circ} \mathrm{C}$ leads to good fusion between the weld metal and the base metal, also a pronounced effect were observed on the structure of the base metal, finer phases are obtained for preheat, however acicular structure was observed for specimen welded without preheat. This change in microstructure morphology leads to a significant change in the mechanical behavior of these alloys, as will be explained in the following section. 


\subsection{Tensile Properties}

The results of the tensile tests for the tested specimens are shown in figures (6-7). Figure 6 shows the variation of the strength as a function of the preheat temperature for different carbon content alloys.

In the literature, there are two equations (mentioned- equations $1 \& 2$ ) [4], to calculate the carbon equivalent. So, these two equations were used in the present work in order to find out the difference between them when applied for the different alloys.

$\mathrm{C} \%=\mathrm{C}+\mathrm{Mn} / 6+(\mathrm{Cr}+\mathrm{MO}+\mathrm{V}) / 5+(\mathrm{Cu}+\mathrm{Ni}) / 15$

$\mathrm{C} \%=\mathrm{C}+\mathrm{Si} / 24+\mathrm{Mn} / 6+\mathrm{Ni} / 40+\mathrm{Cr} / 5+\mathrm{Mo} / 4+\mathrm{V} / 14$

The first equation has been adopted by sub commission $\mathrm{X}-\mathrm{G}$ of the international institute of welding, (all amounts in wt.\%). The second equation is an alternative formula that has been adopted in Japan, [4].

It is noted that, using these two equations gave almost the same values for the equivalent carbon content in the present case, the difference is less than 0.03 .

From the above results, it is quite possible to observe the following points:

1. for the welded alloys without preheating, alloys with higher carbon equivalent content showed higher tensile strength.

2. alloys of carbon equivalent of $1.2 \mathrm{wt} \%$, preheated at $200^{\circ} \mathrm{C}$, showed a value of ultimate tensile strength of $325 \mathrm{MPa}$, that is, the tensile strength has increased by a factor of about 2 .

3- alloys of carbon equivalent of aboul $1.8 \mathrm{wt} \%$ attained the maximum value of its tensile strength (400 MPa) with preheating at $100\left({ }^{\circ} \mathrm{C}\right.$ ), that is, an increase of about $60 \%$ is observed.

4- For alloys of carbon equivalent of about $4.3 \mathrm{wt} \%$, the maximum value of the strength $(640 \mathrm{MPa})$ is obtained after preheating to about $100-150\left({ }^{\circ} \mathrm{C}\right)$, that is an increase of about $20 \%$ is attained.

5. The ductility as measured by the elongation $\%$ up to fracture, was noticed to follow the same behavior of the tensile strength with respect to the preheat cemperature and the carbon equivalent. However, it is quite observed that, all the tested alloys showed low values of ductility due to the higher carbon content of these alloys

Table(4):Effect of Preheat Temperature $\left({ }^{\circ} \mathrm{C}\right)$, on Ductility (Elongation \%)

\begin{tabular}{|c|c|c|c|c|c|c|c|}
\hline$S p$ & $\mathrm{C}_{0}$ & $\mathrm{RT}$ & 100 & 150 & 200 & Ceg & $\mathrm{Ceg}$ \\
\hline \multicolumn{8}{|c|}{ Ductility $\%$} \\
\hline 1 & 06 & 1.2 & 2.6 & 1.0 & 16 & 1.83 & 1.77 \\
\hline 2 & 0.9 & 0.9 & 1.0 & 1.0 & 1.0 & 1.20 & 1.20 \\
\hline 3 & 155 & 24 & 3.7 & 4.4 & 2.3 & 4.27 & 4.32 \\
\hline
\end{tabular}




\section{$\underline{3.3 \text { Corrosion }}$}

From the corrosion results, the current was plotted against the potential for the different alloys as it shown in figure ( $8 \mathrm{a}$ to $\mathrm{h}$ ). From these family of curves, it is possible to observe the followings:

1- For steel of the same carbon content subjected to different preheat temperature, there is a slight increase in the corrosion resistance of about $10 \%$ compared with steel not-preheated (room temperature preheating), this may be due to the presence of relatively high carbon contents such as $\mathrm{Cr}$ in the tested samples in addition to the high percentage of $\mathrm{Cr}$ presented in the weld electrode.

2- The corrosion resistance, as indicated by the value of the passivation current, is increased as the carbon content increases for the same preheat condition, figure $8 \mathrm{e}-8 \mathrm{~h}$.

\section{CONCLUISIONS}

1- Preheating of higb carbon alloy steel improves the tensile properties (strength and ductility) of the tested alloys. The amount of increase of the tensile properties depends on the carbon equivalent of the alloy and the preheating temperature. $\mathrm{An}$ increase of about $100 \%$ is attained for carbon equivalent of about $1.2 \mathrm{wt} \%$. As the carbon equivalent content increases the corresponding amount of increase is reduced to be $60 \%$ and $20 \%$ for carbon equivalent of about 1.8 wt. $\%$ and 4.2 wt $\%$, respectively.

2- The percentage increase in the tensile properties depends on the initial strength of the alloys, it is less for the initially higher strength alloys than the initialiy less strength ones.

3- The resulting values of the ductility, as meaured by the extenstion to fracture, are relatively low values. This may be due to the ligh percenage of the carbon content and the alloying elements, also the need to post- heat treatment to improve the ductility values.

4- Steel of higler carbon content shows higher corrosion resistance. This is observed for different preheat conditions.

5. Preheating shightly increases the corrosion resistance of steels of the same carbon content. 


\section{REFERENCES}

1- S.W. Kang, H.W. Lee, "A Study on Transverse

Cracking and Fatigue Properties of $50 \mathrm{~mm}$ Thick FCAW Weld Metal; Effects of Preheating and Interpass Temperature", Journal of the Korean Welding Society, Vol. 15, No.3, June 1997.

2- Yu N. Gotalsky, " Welding of Low Alloy High Strength Steels Without Preheating and Heat Treatment Providing Full Strength Joints",Paton Welding Journal, Vol.8, No.6, 1996.

3- Kenneth Easterling, "Introduction To The Physical Metallurgy Of Welding", Butterworths Monograph In Metals, 1985.

4-E. A. Avallone and T. Baumeister III, "Marks' Standard Handbook For Mechanical Engineers", 9 ${ }^{\text {llt }}$, ed. , McGraw -. Hill International Editions, Mechanical Engineering Series.1997. 


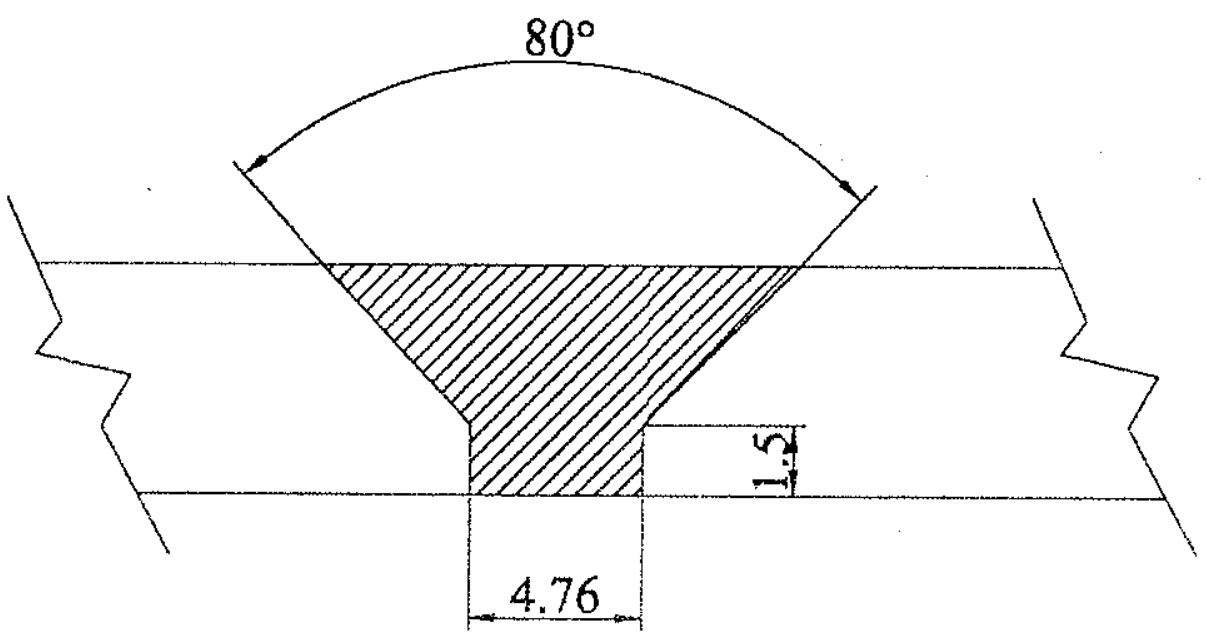

Fig. (1.a) Geometry of weld joint, mms
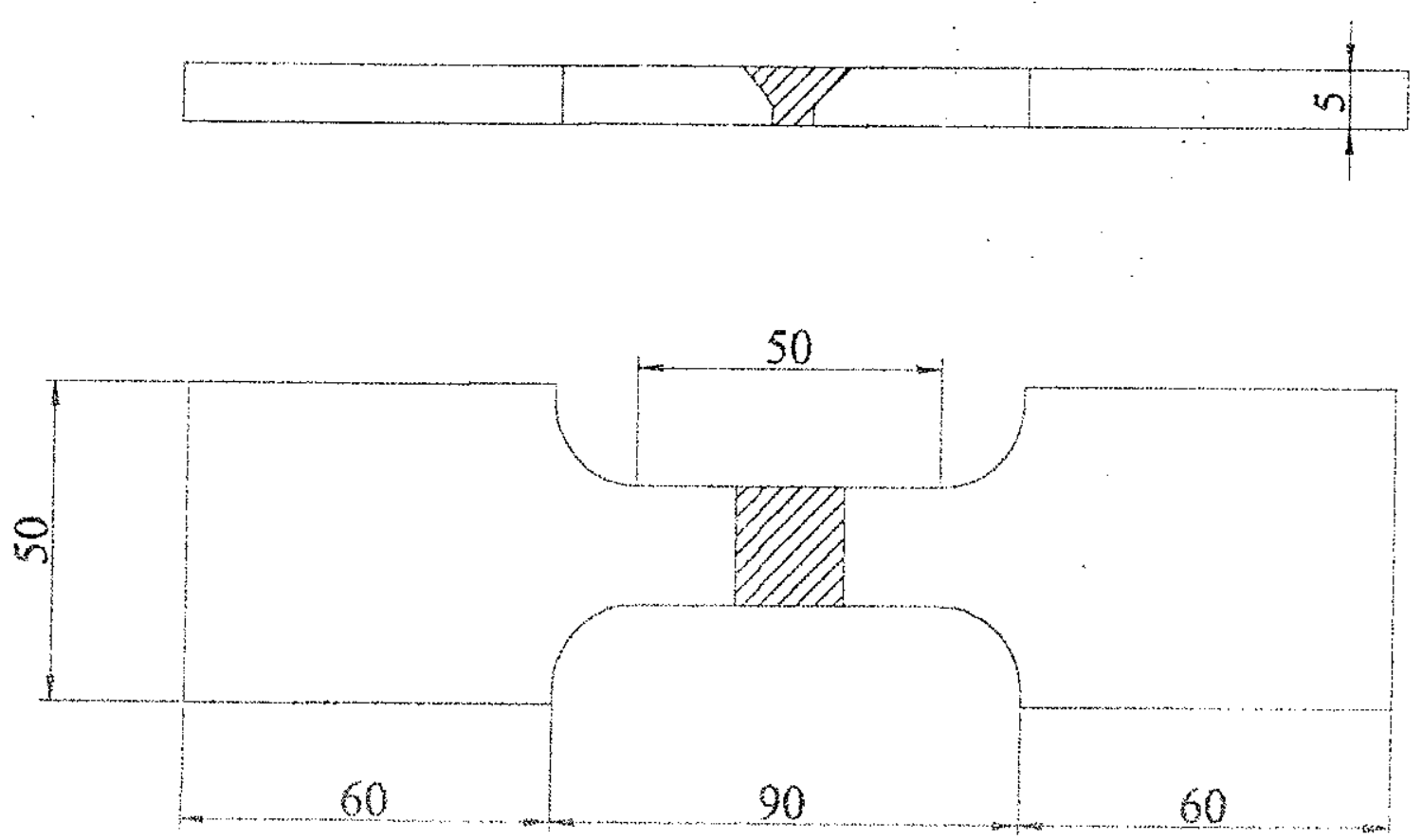

Fig. (1.b) Geometry of tensile specimen, ,nms 

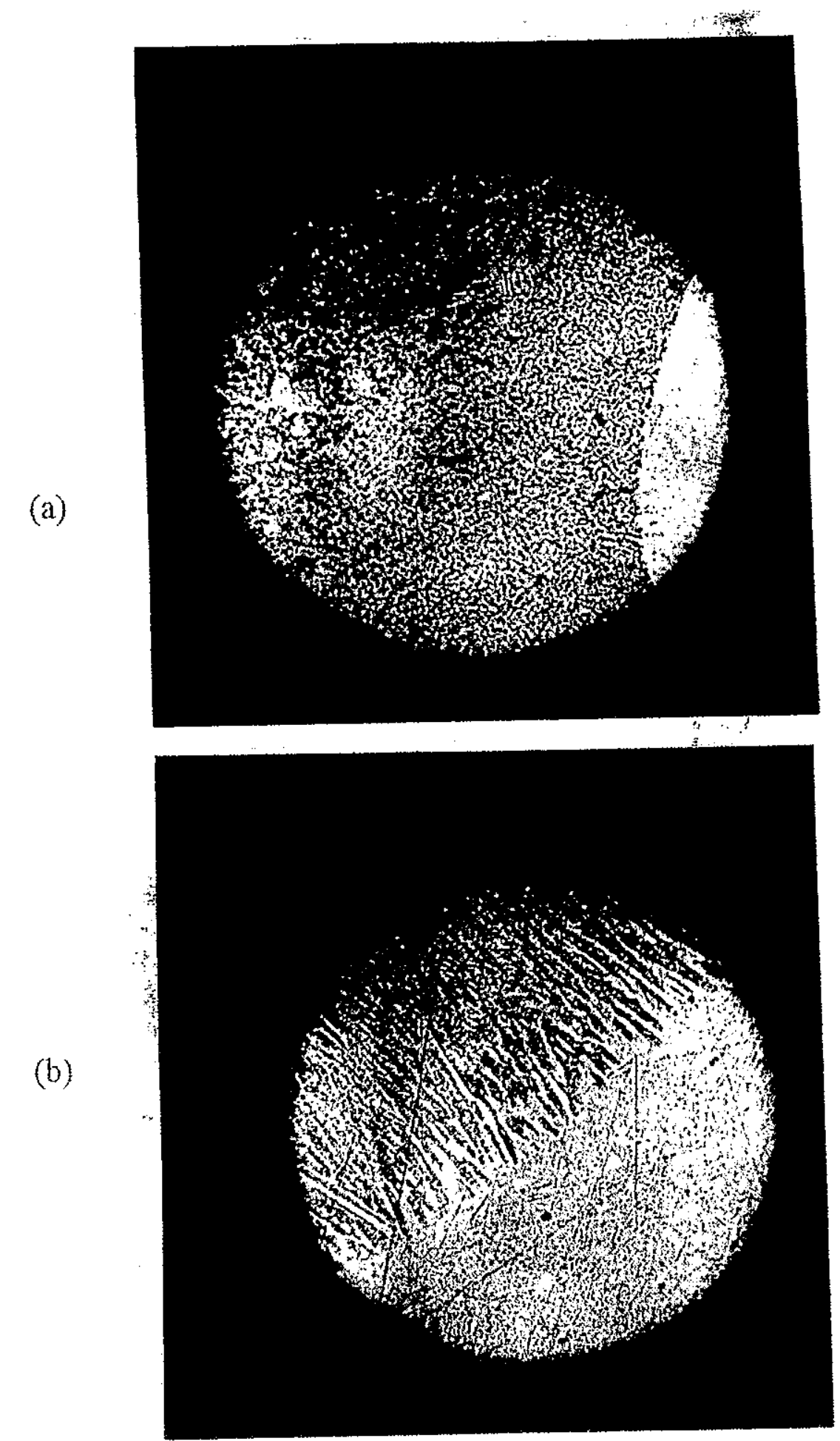

Fig. (2): Microstructure of weld and base metal for specinen 12 of $0.6 \% \mathrm{C}$;
(a): whinout preheat $(100 \mathrm{X})$
(b): with preheat $100^{\circ} \mathrm{C}(200 \mathrm{X})$ 

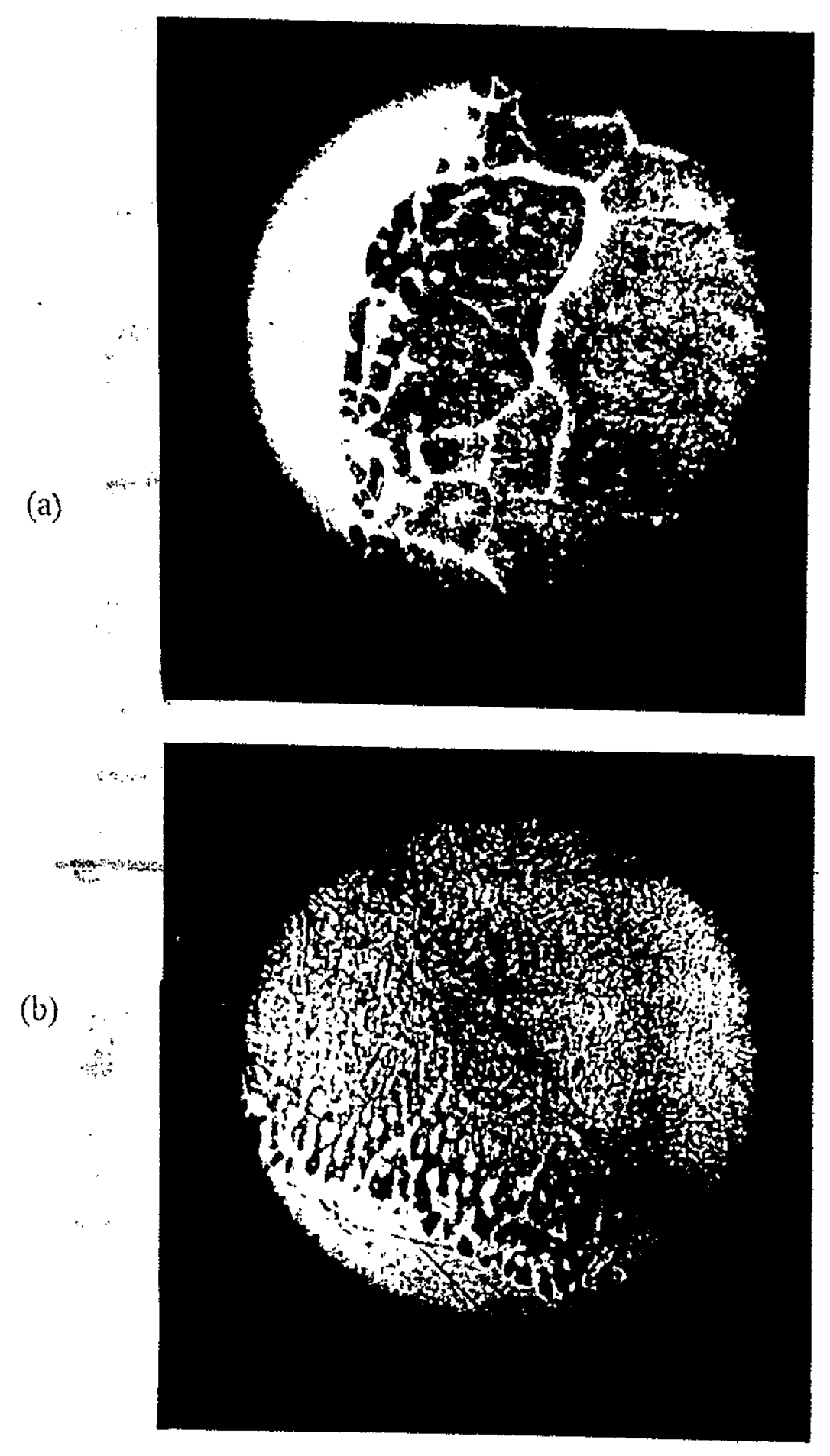

Fig.(3): Microstructure of weld and base metal for specimen $\$ 2$ of $0.9 \% \mathrm{C}$;

$\begin{array}{ll}\text { (a): without preheat }(400 \mathrm{X}) & \text { (b): with preheat } 100^{\circ} \mathrm{C}(400 \mathrm{X})\end{array}$ 
(a)

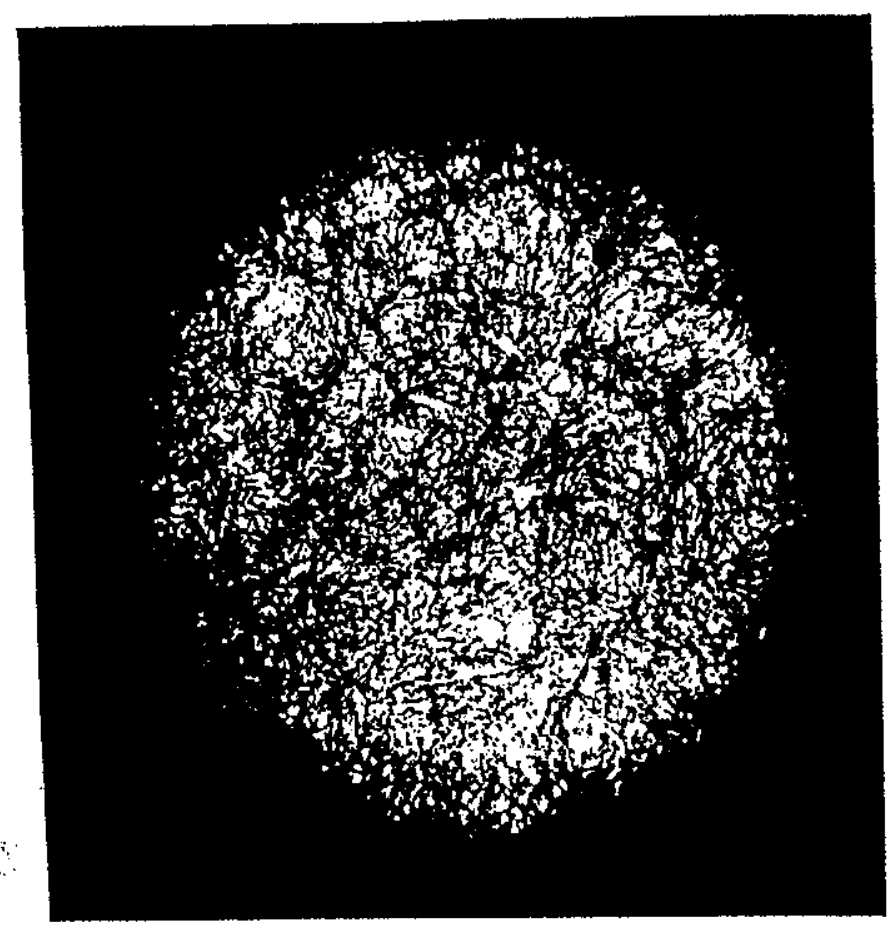

(b)

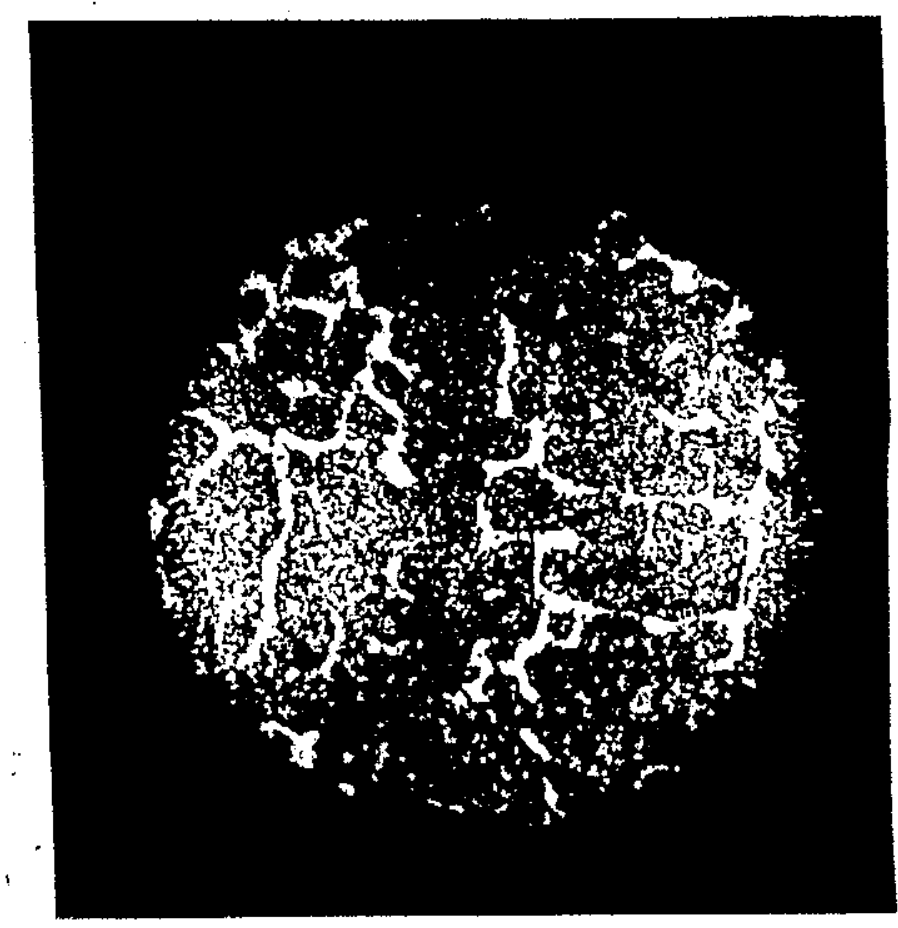

Fig. (4): Microstructure of base metal for specimen $\# 2$ of $0.9 \% \mathrm{C}$; $\begin{array}{ll}\text { (a): without preheat }(600 \mathrm{X}) & \text { (b): with preheat } 200^{\circ}(600 \mathrm{X})\end{array}$ 
(a)

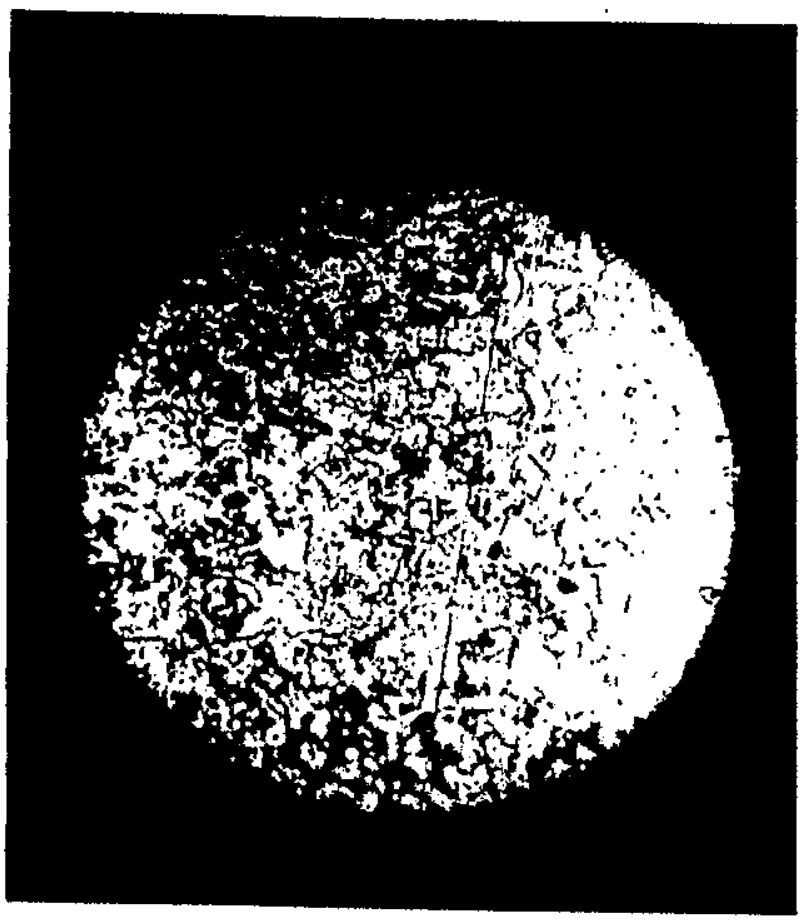

(b)

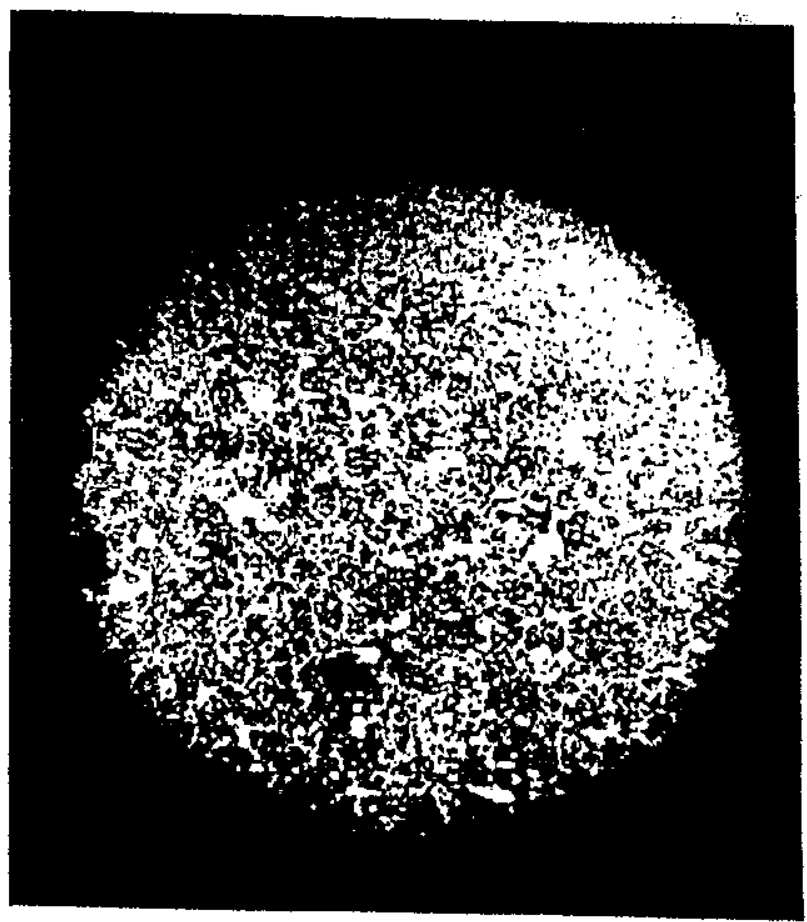

Fig.(5): Microstructure of weld and base metal for specimen \#3 of $1.55 \% \mathrm{C}$,

$\begin{array}{ll}\text { (a): without preheat }(600 \mathrm{X}) & \text { (b): with preheat } 100^{\circ} \mathrm{C}(400 \mathrm{X})\end{array}$ 


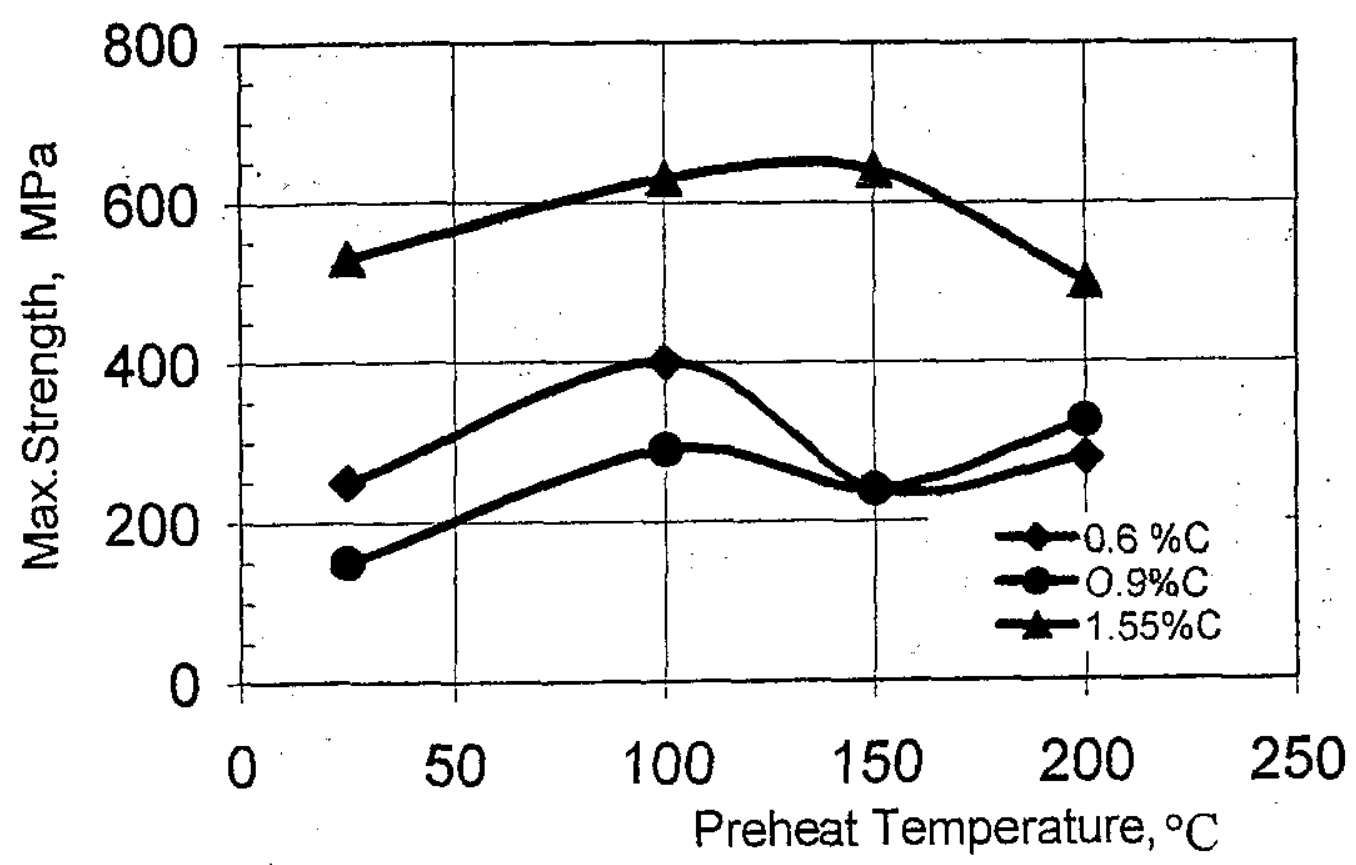

Fig. (6) Effect of preheat temperature on maximum strength for alloys of different carbon content

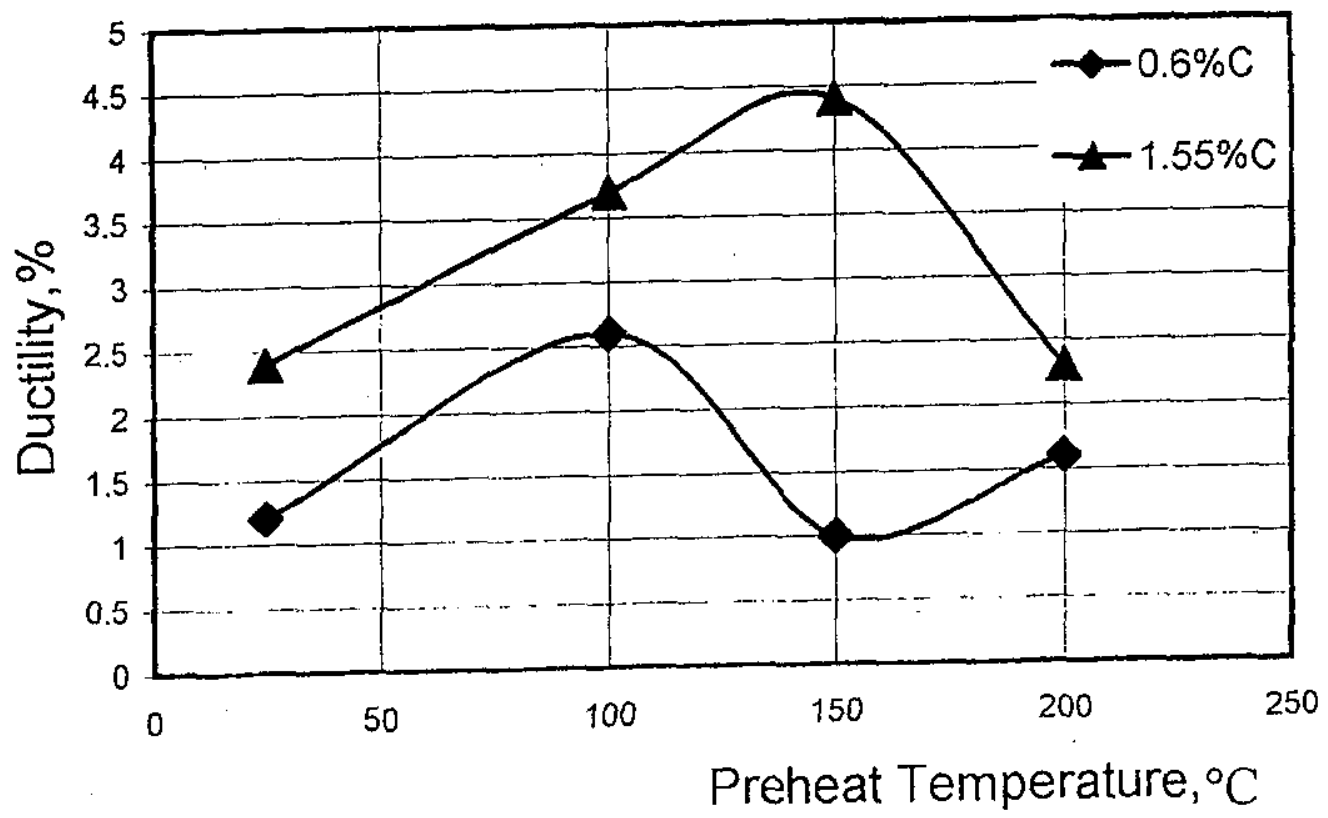

Fig. (7) Effect of preheat temperature on ductility for alloys of different carbon content 


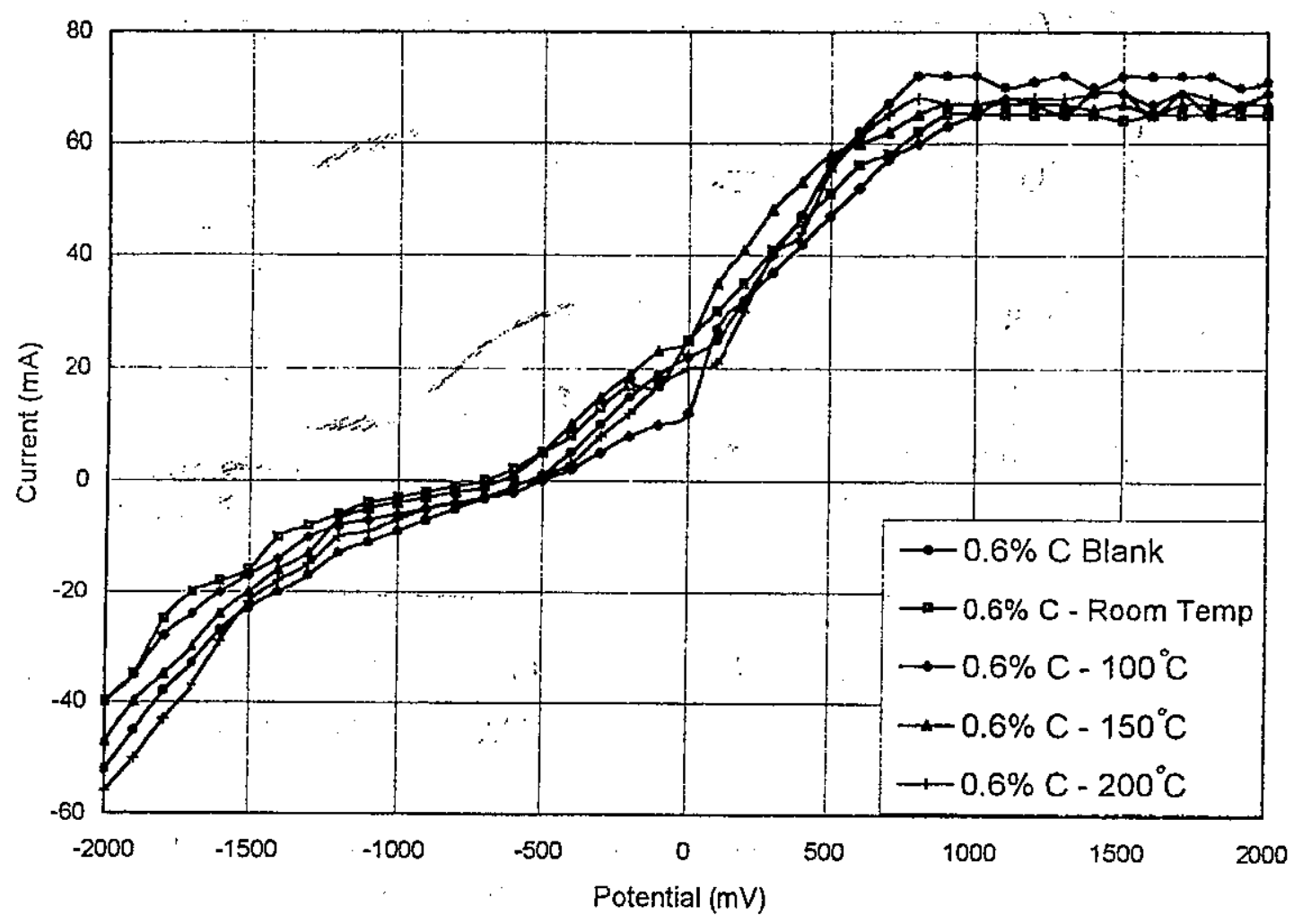

Fig 8-a Effect of different preheat temperatures on corrosion for $0.6 \% \mathrm{C}$

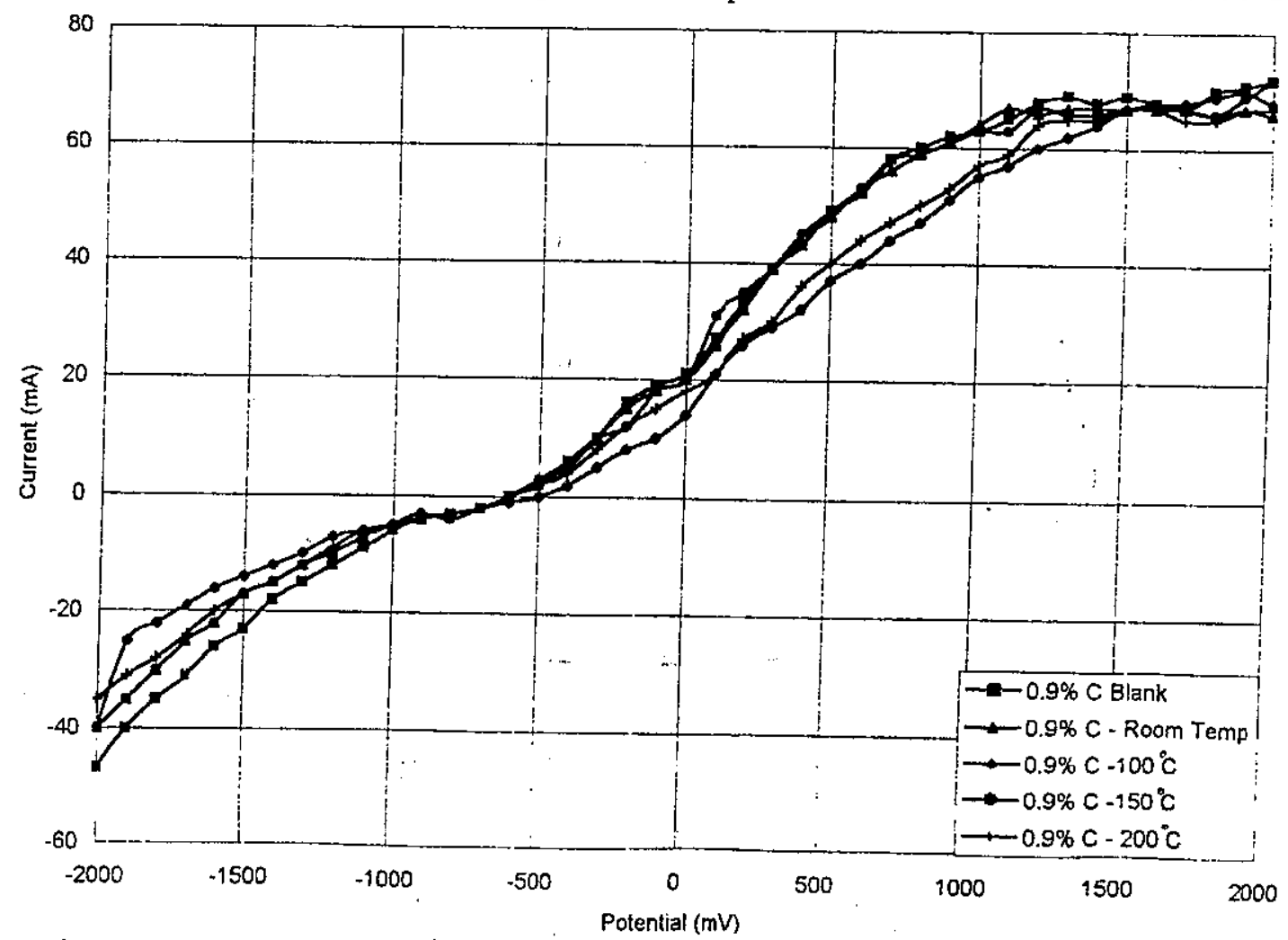

Fig 8-b Effect of different preheat temperatures on corrosion for $0.9 \% \mathrm{C}$ 


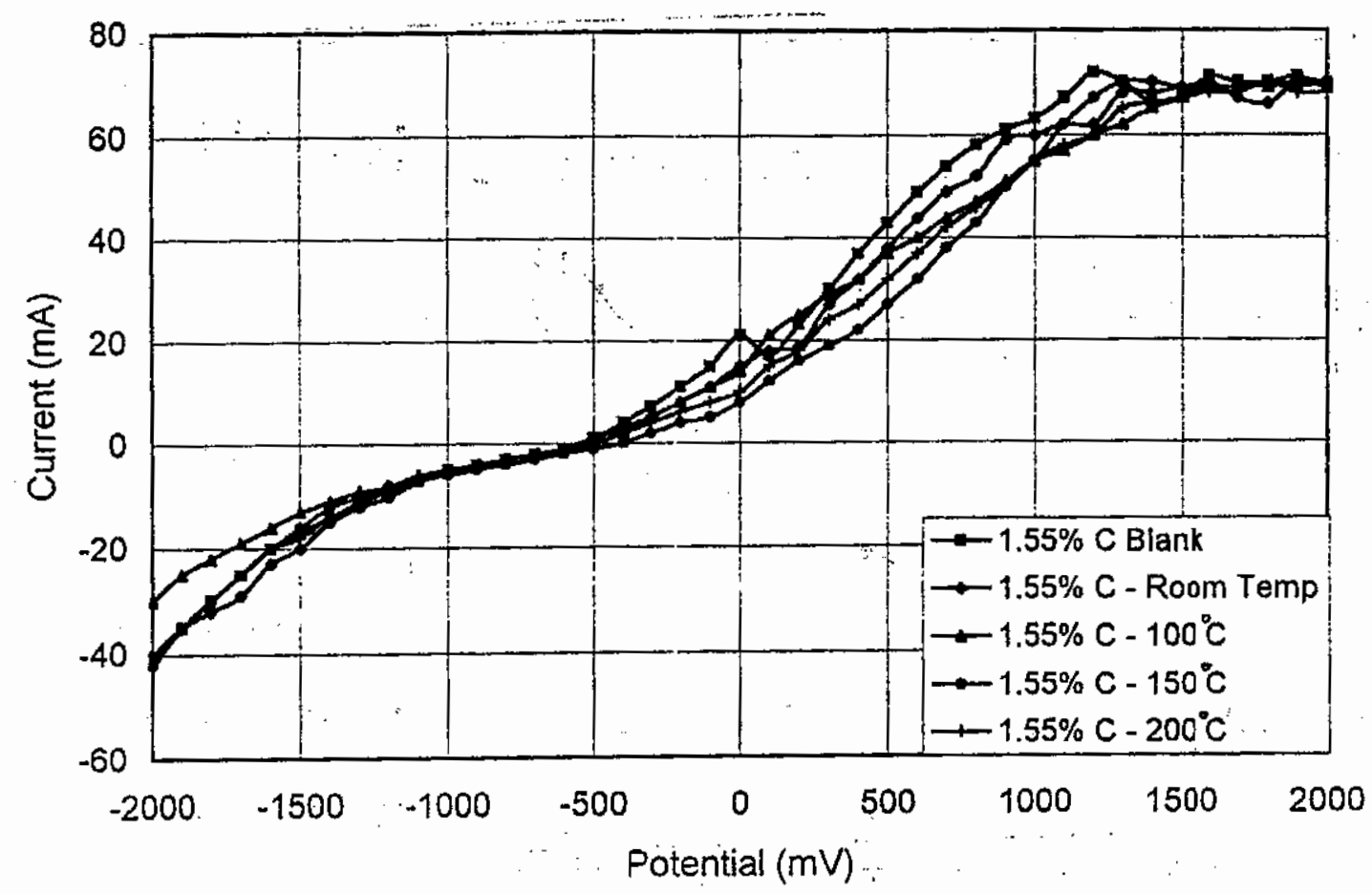

Fig 8-c Effect of different preheat temperatures on corrosion for $1.55 \% \mathrm{C}$

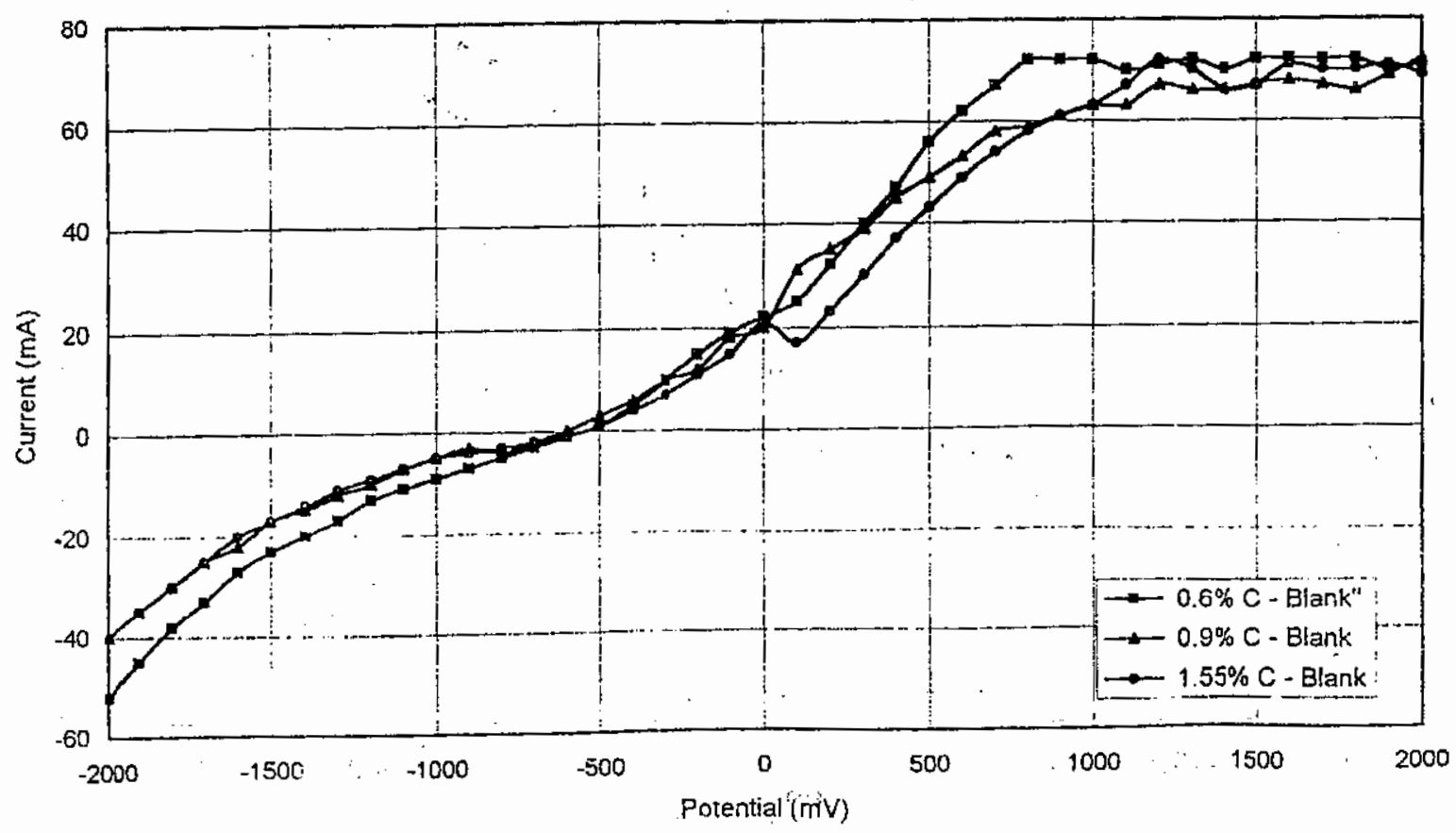

Fig 8-d Effect of carbon content on corrosion for blank alloys 


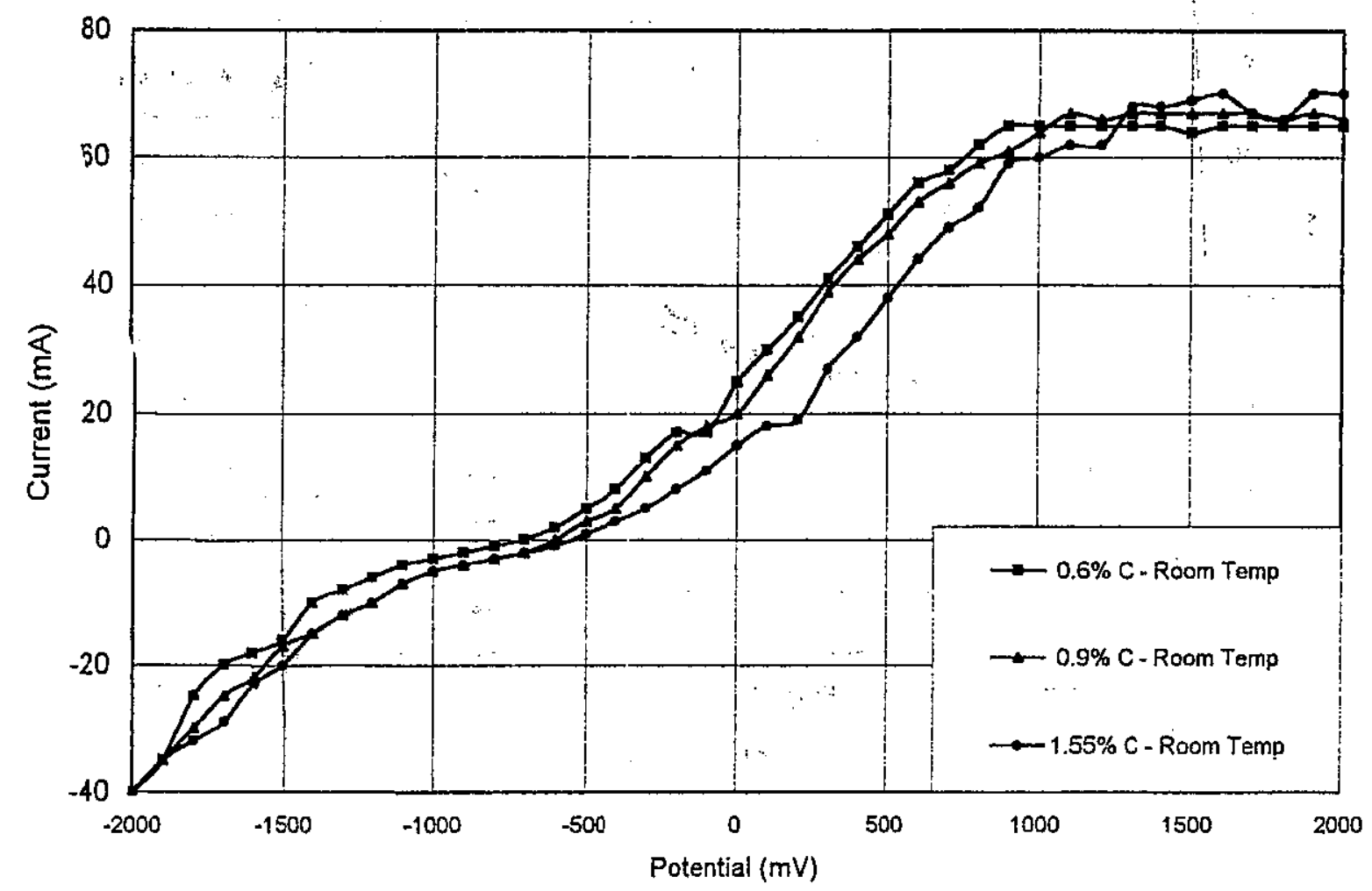

Fig 8-e Effect of carbon content on corrosion for room temp.preheat

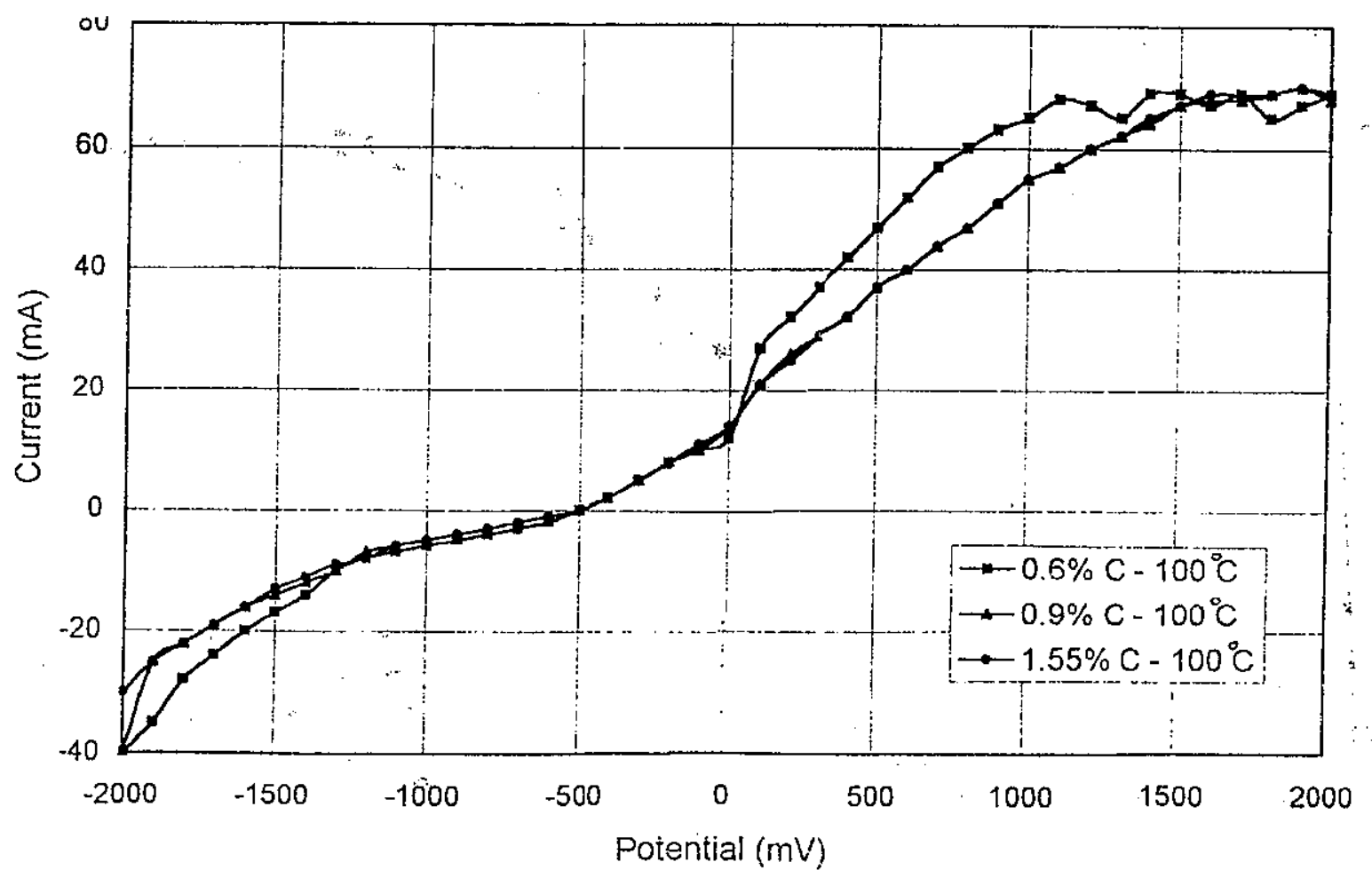

Fig 8-f Effect of carbon content on corrosion for $100{ }^{\circ} \mathrm{C}$ preheat 


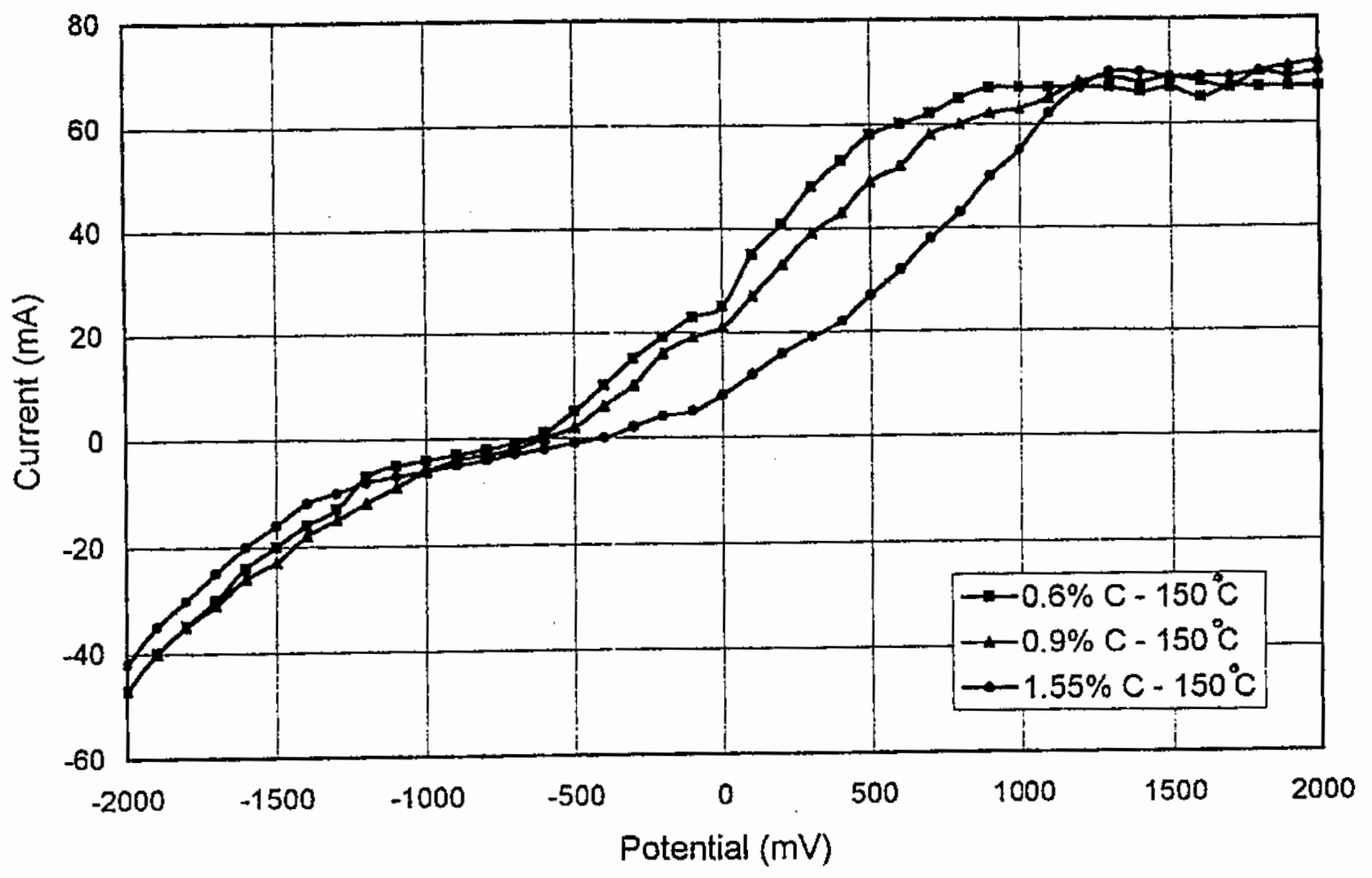

Fig 8-g Effect of carbon content on corrosion for $150^{\circ} \mathrm{C}$ preheat

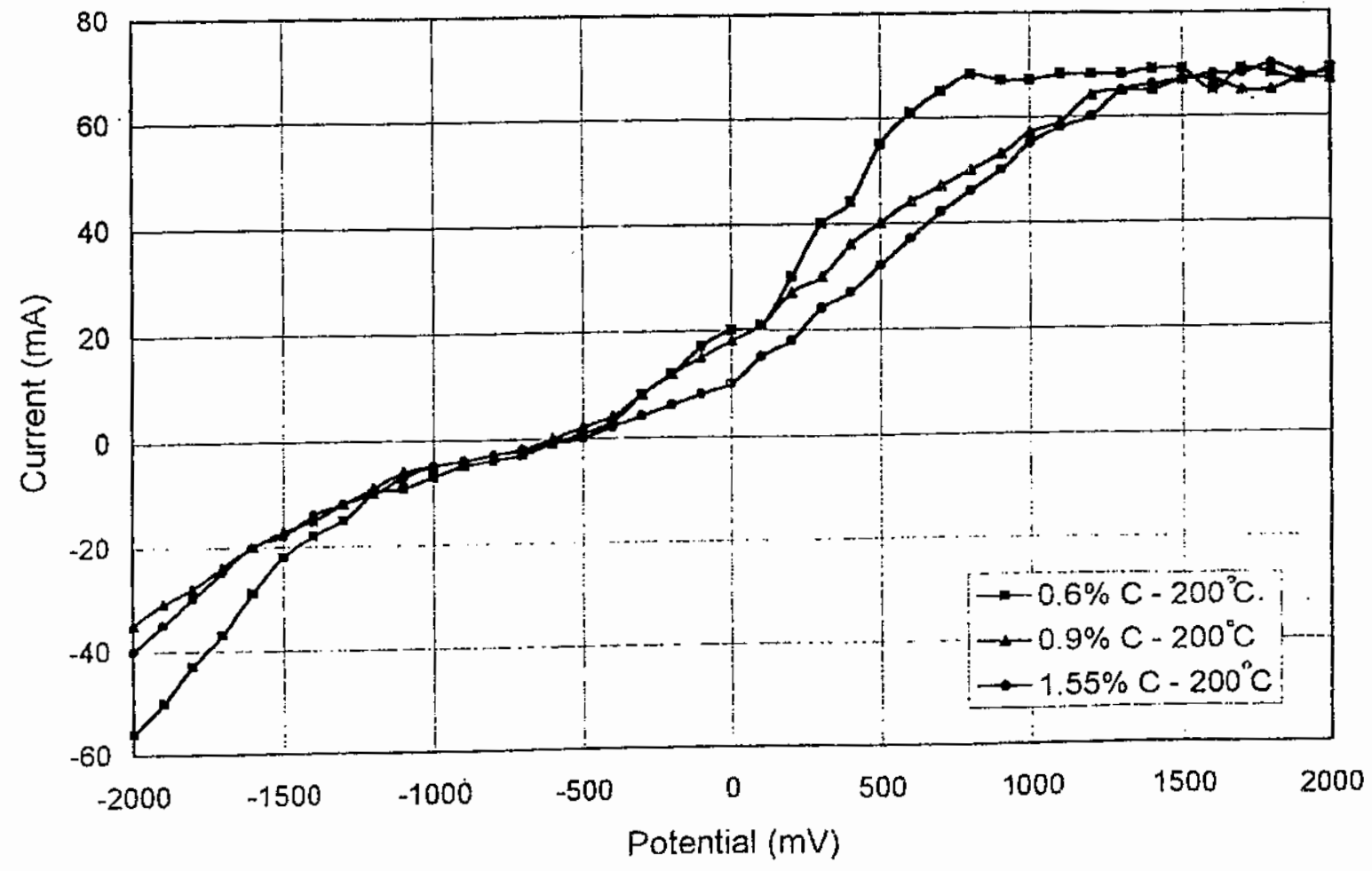

Fig 8-h Effect of carbon content on corrosion for $200^{\circ} \mathrm{C}$ preheat 
تأثير التسخين المسبق على الشد والتاككل الكيميائى لو لوحلات الصلب الملحومة

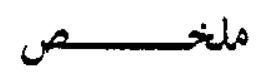

أن الصلب عالى الكربون، بصفة عامة ،لهه متانة عالية تجعله مطلوب في كثير من التطبيقات

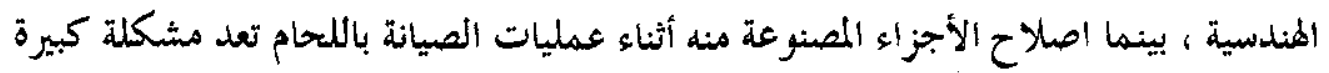

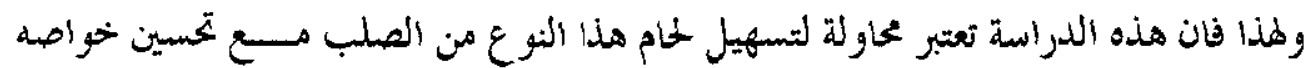

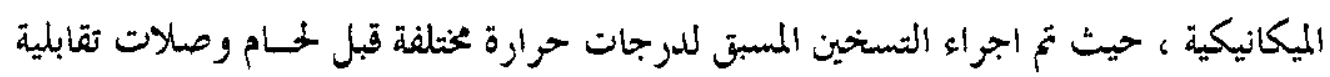

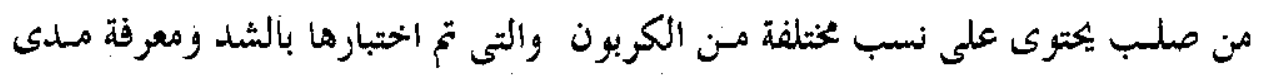

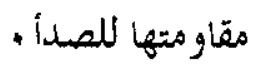

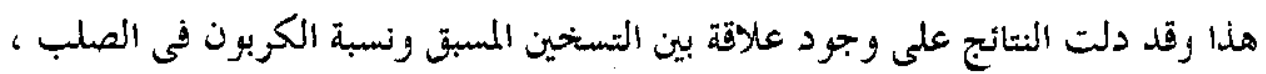

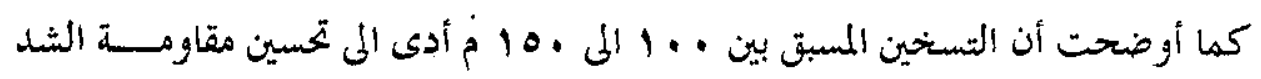

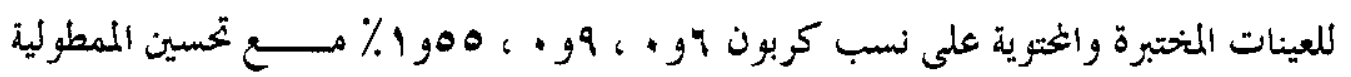

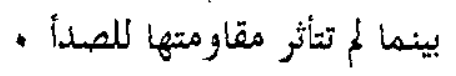

